\title{
Histological and biomechanical effects of zoledronate on fracture healing in an osteoporotic rat tibia model
}

\author{
Osteoporotik sıçan tibiası modelinde zoledronatın kııık kaynamasında \\ histolojik ve biyomekanik etkileri
}

\author{
Mehmet Türker, MD., ${ }^{1}$ Arif Aslan, MD., ${ }^{2}$ Meriç Çırpar, MD., ${ }^{3}$ Alauddin Kochai, MD.,1 \\ Özlem Banu Tulmaç, ${ }^{4}$ MD., Mahi Balcı, MD. ${ }^{5}$ \\ 'Department of Orthopedics and Traumatology, Medical Faculty of Sakarya University, Sakarya, Turkey \\ ${ }^{2}$ Department of Orthopedics and Traumatology, Yeni Mahalle State Hospital, Ankara, Turkey \\ ${ }^{3}$ Department of Orthopedics and Traumatology, Medical Faculty of Kırıkkale University, Kırıkkale, Turkey \\ ${ }^{4}$ Department of Gynecology and Obstetrics, Medical Faculty of Kırıkkale University, Kırıkkale, Turkey \\ ${ }^{5}$ Department of Pathology, Medical Faculty of Kırıkkale University, Kırıkkale, Turkey
}

\begin{abstract}
Objectives: This study aims to investigate the effects of zoledronate therapy on histological and biomechanical properties of bone healing via a fracture model generated on osteoporotic rat tibiae.

Materials and methods: Ovariectomized 40 Wistar-Dawley female rats weighing $300 \mathrm{~g}$ to $350 \mathrm{~g}$ were used in the study. After one week, $2 \mathrm{IU} / \mathrm{g}$ heparin injection was started subcutaneously. After four weeks of daily injections, osteoporosis was ensued proven with bone mineral density measurements. Osteoporotic rats were separated into four equal groups randomly as group A (control), group B (calcium and vitamin D), group C $(0.1 \mathrm{mg} /$ $\mathrm{kg}$ subcutaneous zoledronic acid), and group D (calcium and vitamin D / $0.1 \mathrm{mg} / \mathrm{kg}$ subcutaneous zoledronic acid). Six weeks later, all rats were sacrificed, their tibiae were resected, and histopathologic and biomechanical studies were performed.

Results: Group C $(30.2 \pm 1 \mathrm{Nm})$ and group D $(33.3 \pm 3 \mathrm{Nm})$ had significantly higher peak torque values than group $\mathrm{A}(21.6 \pm 6 \mathrm{Nm})$ and group $\mathrm{B}(23.6 \pm 4 \mathrm{Nm})(\mathrm{p}=0.007$ and $\mathrm{p}=0.005$, respectively). Group C (1.8) and group D (2.0) had higher stiffness values than group A (1.4) and group B (1.7); however, the difference was not statistically significant ( $\mathrm{p}>0.05$ for all).
\end{abstract}

Conclusion: According to histopathological and biomechanical test results, single dose zoledronic acid treatment improves fracture healing in an osteoporotic rat fracture model. Orally administered daily calcium and vitamin D treatment had no effect on fracture healing. There was no additional improvement in fracture healing when calcium and vitamin D treatment was added to zoledronic acid treatment. Positive effects of zoledronic acid treatment on osteoporotic fracture healing and callus quality should be shown by future clinical studies.

Keywords: Bone healing; osteoporosis; zoledronic acid.

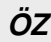

Amaç: $\mathrm{Bu}$ çalışmada zoledronat tedavisinin osteoporotik sıçan tibialarında oluşturulan kırık modeli üzerinde kemik iyileşmesinin histolojisi ve biyomekanik özelliklerine etkileri araştırıld1.

Gereç ve yöntemler: Çalışmada ağırlıkları $300 \mathrm{~g}$ - $350 \mathrm{~g}$ olan ovariektomi yapılmış 40 adet Wistar-Dawley dişi sıçan kullanıldı. Bir hafta sonra, $2 \mathrm{IU} / \mathrm{g}$ subkütan heparin tedavisine başlandı. Günlük enjeksiyonlarla dört hafta sonra, kemik mineral yoğunluğu ölçümü ile kanıtlanmış osteoporoz oluşturuldu. Osteoporotik siçanlar grup A (kontrol), grup B (kalsiyum ve $\mathrm{D}$ vitamini), grup C (0.1 $\mathrm{mg} / \mathrm{kg}$ subkütan zoledronik asit) ve grup D (kalsiyum ve D vitamini / $0.1 \mathrm{mg} / \mathrm{kg}$ subkütan zoledronik asit) olarak rastgele dört eşit gruba ayrıldı. Altı hafta sonra, bütün sıçanlar sakrifiye edildi, tibiaları çıkartıldı ve histopatolojik ve biyomekanik incelemeler yapıldı.

Bulgular: Grup C $(30.2 \pm 1 \mathrm{Nm})$ ve grup D’nin $(33.3 \pm 3 \mathrm{Nm})$ tork değerleri grup A $(21.6 \pm 6 \mathrm{Nm})$ ve grup B'den $(23.6 \pm 4 \mathrm{Nm})$ anlamlı olarak daha yüksek idi (sırasıly $\mathrm{p}=0.007$ ve $\mathrm{p}=0.005$ ). Grup $\mathrm{C}$ (1.8) ve grup D'nin (2.0) sertlik değerleri, grup A (1.4) ve grup B'den (1.7) daha yüksekti, ancak farklılık istatistiksel olarak anlamlı değildi (hepsi için $\mathrm{p}>0.05$ ).

Sonuç: Histopatolojik ve biyomekanik test sonuçlarına göre, tek doz zoledronik asit tedavisi osteoporotik sıçan kırık modelinde kırık iyileşmesini artırdı. A $\breve{g}_{1 z}$ yoluyla verilen günlük kalsiyum ve D vitamini tedavisinin kırık iyileşmesi üzerinde etkisi yoktu. Zoledronik asit tedavisine kalsiyum ve D vitamini tedavisi eklendiğinde, kırık iyileşmesinde ek bir artış olmadı. Zoledronik asit tedavisinin osteoporotik kırık iyileşmesi ve kallus kalitesine olumlu etkileri gelecek klinik çalışmalarla gösterilmelidir.

Anahtar sözcükler: Kırık iyileşmesi; osteoporoz; zoledronik asit.

- Received: November 23, 2015 Accepted: December 16, 2015

- Correspondence: Mehmet Türker, MD. Sakarya Üniversitesi Tıp Fakültesi Ortopedi ve Travmatoloji Anabilim Dalı, 54050 Adapazarı, Sakarya, Turkey، Tel: +90 264 - 8884003 Fax: +90264-2759192 e-mail: meturker@yahoo.com 
Osteoporosis is a disease of elderly people which results in enhanced bone fragility and increased fracture risk due to lowered bone mass and altered microarchitectural bone framework. ${ }^{[1]}$ This metabolic skeletal disorder creates a high burden for health care systems with increased fracture risk and for the patients with complications such as increased morbidity and mortality. ${ }^{[2,3]}$

The most commonly used drugs for osteoporosis in clinical practice are bisphosphonates. ${ }^{[4-6]}$ Zoledronic acid is the most potent bisphosphonate that has been shown to significantly reduce the risk of fractures in patients who receive yearly doses for treatment of postmenopausal osteoporosis. ${ }^{[7,8]}$

Although osteoporotic fracture healing follows the same paths as in normal bone, the result is a weakened callus with diminished load carrying capacity and possible delayed healing and nonunion. Considering the poor quality and quantity of bone in osteoporosis, there are efforts to enhance fracture healing in this situation. ${ }^{[9-11]}$

In treatment of osteoporosis, vitamin D3 (vitD3) and calcium supplementation has been considered a baseline therapy. It has been shown that administration of antiresorptive agents sustains or increases bone mass by suppressing bone resorption while maintaining normal bone formation. Up to date, many studies have been conducted on animal models with different pharmaceutical agents in order to enhance fracture healing in normal situations. ${ }^{[8,10,12]}$ However, studies on osteoporotic animal models are lacking. Pharmaceutical agents, either systemically or locally applied, have been proposed to enhance fracture healing and callus strength in osteoporotic fractures. ${ }^{[13-15]}$

In this study, we aimed to investigate the effects of zoledronate therapy on histological and biomechanical properties of bone healing via a fracture model generated on osteoporotic rat tibiae.

\section{MATERIALS AND METHODS}

This study was approved by the Ethical Committee of Kirıkkale University with the number of 2012-82 and conducted at Kobay laboratories. The closed, standardized diaphyseal fracture model in this study was adopted from Bonnarens and Einhorn, ${ }^{[16]}$ and combined with post-ovariectomy osteoporosis model with heparin administration to induce osteoporosis. ${ }^{[17]}$

\section{Experimental animals}

Forty female 14-week-old Wistar-Dawley rats were used. All the animals were in house laboratory ad libitum fed until they reached $300 \mathrm{~g}$ to $350 \mathrm{~g}$ of weight. No other additional nutrients were added to their diet. Bone mineral densities of four randomly chosen rats were calculated by dual emission bone absorptiometry (Hologic NV/SA, Belgium).

\section{Initial surgical procedure}

The study had a preliminary process in order to achieve osteoporotic rats. All rats were operated under Xylazine (Rompun, Bayer, Turkey) anesthesia at $10 \mathrm{mg} / \mathrm{kg}$ dosing for ovariectomy. Cephazoline sodium (Sefazol, Mustafa Nevzat, Turkey) was administered for antibiotic prophylaxis at $15 \mathrm{mg} /$ $\mathrm{kg}$ dosing preoperatively. Before surgical incision, abdomen was shaved and prepared with 7.5\% povidone iodine solution (Batticon, Adeka, Turkey). Ovariectomies were performed by midline incision in a standard fashion. Sham operations were also performed.

All rats except the ones in control group were treated with daily administration of $2 \mathrm{IU} / \mathrm{g}$ subcutaneous heparin (Nevparin, Mustafa Nevzat Turkey). After four weeks of heparin treatment, four rats were randomly chosen for reassessment of their bone mineral density. Significant reduction of bone mineral density was confirmed and second part of the study was ensued.

TABLE I

Maximum failure load, maximum failure angle and rotational stiffness values

\begin{tabular}{lccccc}
\hline & $\begin{array}{c}\text { Peak torque } \\
(\mathrm{Nmm})\end{array}$ & $\begin{array}{c}\text { Angle at peak torque } \\
\text { (degree) }\end{array}$ & $\begin{array}{c}\text { Peak angle } \\
\text { (degree) }\end{array}$ & $\begin{array}{c}\text { Yield torque } \\
(\text { Nmm })\end{array}$ & $\begin{array}{c}\text { Stiffness } \\
(\mathrm{E})\end{array}$ \\
\hline Control & $21.6 \pm 6$ & $16.2 \pm 4$ & $22.4 \pm 4$ & $20.3 \pm 5$ & $1.4 \pm 0.4$ \\
Zoledronic acid & $33.3 \pm 5^{*}$ & $18.9 \pm 3$ & $19.8 \pm 3$ & $30.5 \pm 6^{*}$ & $2.0 \pm 0.4$ \\
Ca vitD & $23.6 \pm 4$ & $15.3 \pm 4$ & $16.7 \pm 4$ & $21.7 \pm 3$ & $1.7 \pm 0.4$ \\
Zol + Ca vitD & $30.2 \pm 10^{* *}$ & $18.1 \pm 9$ & $20 \pm 10$ & $28.6 \pm 10^{* *}$ & $1.8 \pm 0.8$ \\
\hline
\end{tabular}

Zol: Zoledronic; Ca vitD: Calcium and vitamin D; * Peak torque and yield torque in zoledronic acid group were significantly higher than control and calcium and vitamin D groups, $\mathrm{p}=0.005 ;{ }^{* *}$ Peak torque and yield torque in zoledronic acid + calcium and vitamin $\mathrm{D}$ groups were significantly higher than control and calcium and vitamin $\mathrm{D}$ groups, $\mathrm{p}=0.007$. 


\section{Second surgical procedure}

The control group $(n=10)$ and 30 rats which were ovariectomized and treated with daily heparin administration underwent a secondary surgical operation as described by Taguchi et al. ${ }^{[18]}$ and Uchida et al. ${ }^{[19]}$ Both tibiae of the rats were prepared for surgery as described above and a fracture model was created by drilling a hole in proximal tibial metaphysis.

\section{Study groups}

Except the 10 rats in the control group (group A), which had no other additional nutrients in their diet, 30 rats were randomly allocated to three different treatment groups. Group B was treated by daily oral administration of calcium and $0.1 \mu \mathrm{g} / \mathrm{kg} /$ day vitamin $D$ with oral gavage. Group $\mathrm{C}$ was treated by intravenous administration of zoledronic acid one day after the second operation. Group D was treated by combination of treatments given to group B and C. Zoledronic acid was administered to groups $C$ and D subcutaneously at a dose of $0.1 \mathrm{mg} / \mathrm{kg}$ two weeks after the second operation to mimic the real scenario of daily practice. All the rats were allowed to live in separate cages with free access to water and fed ad libidum.

Six weeks after the index operation, rats were sacrificed under ethylene anesthesia and their tibiae were harvested and freed of their soft tissues.

\section{Histological examination}

Two tibiae of each group were kept in 10\% formaldehyde for four days and then embedded in $10 \%$ formic acid for 15 days to achieve decalcification. Then, these eight tibiae were embedded in paraffin and $4 \mu \mathrm{m}$ longitudinal sections were obtained and stained with hematoxylin-eosin for microscopic evaluation.

\section{Biomechanical testing}

A total of 32 tibiae were prepared to assess their biomechanical properties. Both sides of tibiae were embedded in polymethymetaacrylate fast setting cement. A special podium and a socket were used to axially align the tibiae. Special socket served as cement molder for easy fixation on the jaws of material testing machine. Biomechanical properties were assessed by Instron 55MT2 Electromechanical Testing Machine, Partner Torsional Stiffness Software (Instron Co., Norwood, MA, USA). All specimens were tested torsionally at a load to failure rate of 2.5 degree/ second. Maximum load to failure value in terms of $\mathrm{Nm}$ and maximum rotational displacement in terms of degree were the parameters used in statistical analysis. Torsional stiffness of the specimens was calculated from the slope of the curve and also used for statistical analysis.

\section{Statistical analysis}

All data were expressed as mean \pm standard deviation. For all data, comparisons between different

(a)

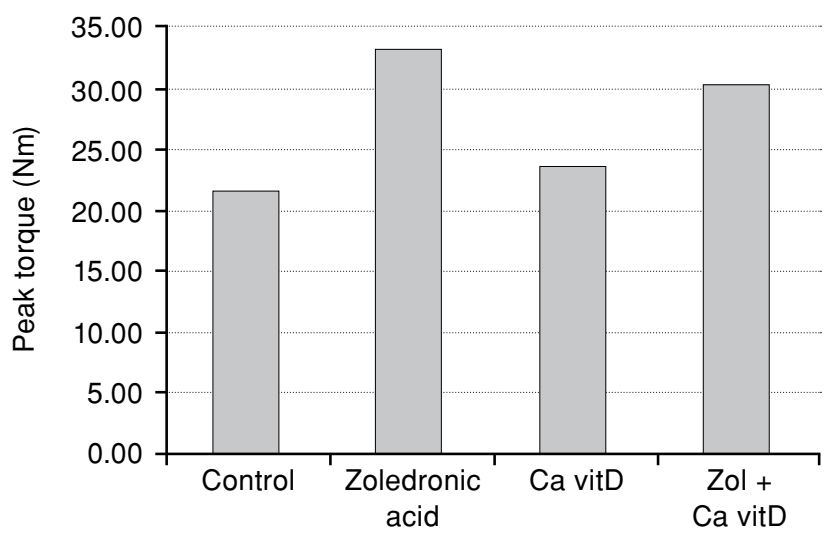

(b)

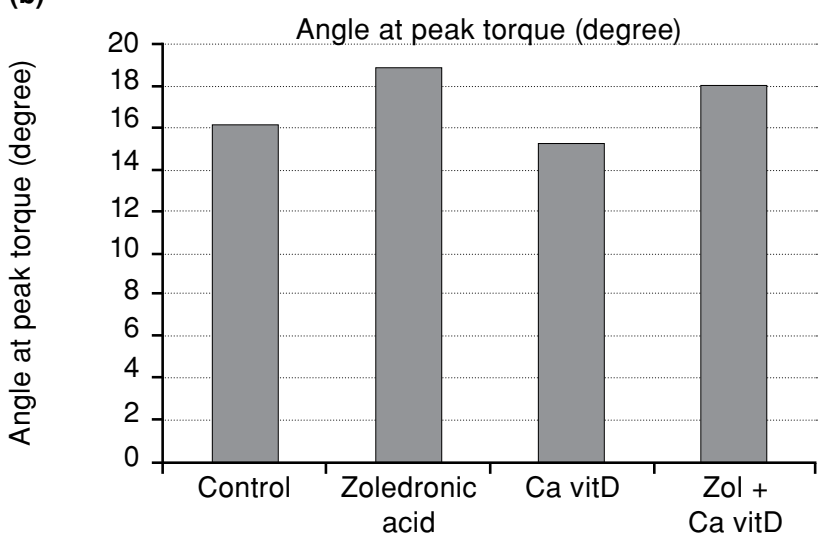

(c)

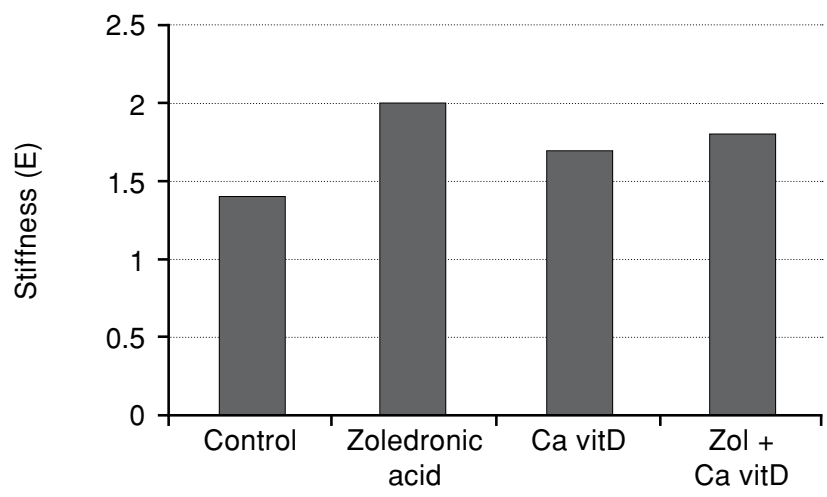

Figure 1. (a) Maximum failure load graphics of groups. (b) Maximum failure angle graphics of groups. (c) Rotational stiffness graphics of groups. Schematic representation of maximum failure load, maximum failure angle and rotational stiffness are also given. Peak torque was significantly higher for zoledronic acid group. Ca VitD: Calcium and vitamin D; Zol: Zoledronic. 
treatments were analyzed by Kruskall-Wallis $\mathrm{H}$ test. If Kruskall-Wallis $\mathrm{H}$ test yielded significant results, Mann-Whitney $U$ test with Bonferroni corrections were used for multiple comparisons. For all analyses, SPSS version 16.0 software (SPSS Inc., Chicago, IL, USA) were used.

\section{RESULTS}

\section{Verification of osteoporosis}

Four rats were randomly chosen from each group before the initial operation. Their bone mineral densities were assessed by bone densitometry (Hologic NV/SA, Belgium). After the first operation and ongoing daily heparin treatment, rats were again randomly chosen from each group and their bone mineral densities were reassessed. The final mean bone mineral density values decreased significantly from $0.1497 \mathrm{~g} / \mathrm{cm}^{2}$ to $0.1268 \mathrm{~g} / \mathrm{cm}^{2} \quad(\mathrm{p}<0.023)$. This corresponds to $18.4 \%$ decrease in bone mineral density.

\section{Biomechanical test results}

All tibiae were examined macroscopically after completion of the biomechanical tests. In all failed tibiae, the mode of failure was a spiral fracture line extending into the drill hole. Peak torque, peak angle, angle at peak torque, yield torque, and rotational stiffness values with their significance values in brackets are given in Table 1. Figure 1a-c shows maximum failure load graphics, maximum failure angle graphics, and rotational stiffness graphics of all groups.

\section{Histological results}

Histological examination of the specimens revealed that bone healing was completed in all

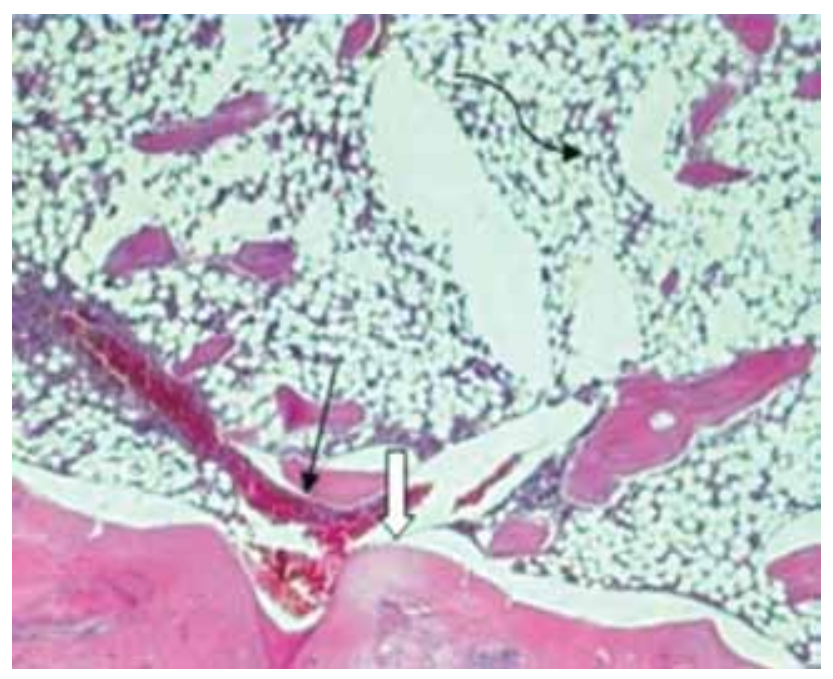

Figure 2. Straight black arrow shows hemorrhage of drilling, while white arrow shows process of mature lamellar bone. Curved arrow is osteoporotic changes of medullar cavity. groups. Osteoporotic changes were seen in medulla of the specimens in groups A and B. In groups A and B, callus volume was significantly lower than in groups $\mathrm{C}$ and D (Figure 2).

Specimens in groups $C$ and D had thicker and more mature bone trabeculae than groups $\mathrm{A}$ and B. Abundant cement lines were also seen in groups $\mathrm{C}$ and $\mathrm{D}$, which were absent in groups $\mathrm{A}$ and $\mathrm{B}$. Presence of abundant cement lines were suggestive of increased bone formation. Bone healing was in remodeling phase (Figure 3).

Histological examination results of the specimens in group $\mathrm{D}$ were nearly the same with the specimens in group C (Figure 4).

\section{DISCUSSION}

The most important finding of this study is the enhancement of both biomechanical and histological bone parameters in an osteoporotic rat model after treatment with zoledronic acid. Zoledronic acid treatment increased peak torque at failure, yield torque and stiffness without changing angle at peak torque of osteoporotic rat tibia.

Many of the studies about osteoporosis are conducted in nonosteoporotic species which might hinder the effects of osteoporotic agents. In this study, we used the osteoporotic model of Ozturan et al. ${ }^{[20]}$ and proved the establishment of osteoporosis with ovariectomy and heparin treatment with dual X-ray absorptiometry measurements. This osteoporotic bone architecture offered a suitable milieu for exploration of net effect of zoledronic acid. The net effect of estrogen deficiency is decreased bone mass due to increased bone resorption secondary to increased osteoclastic activity and decreased new bone formation secondary to decreased osteoblastic lifespan. ${ }^{[21]}$

In another study, increased levels of tartaric resistant acid phosphatase (TRAP) were shown in blood samples of ovariectomized rats. ${ }^{[22]}$ Combination therapy with zoledronic acid and vitD3 had the most pronounced effect in decreasing serum levels of TRAP which is a measure of bone resorption. Khajuria et al. ${ }^{[23]}$ showed that zoledronic acid plus vitD treatment had the most significant effect on return to the preovaricetomy bone strength and morphology. In contrast to their findings, we did not observe any additional effect of dietary vitD3 on bone strength and morphology. This difference might be due to the net oral ingestion of calcium and $0.1 \mu \mathrm{g} / \mathrm{kg} /$ day vitD3 in rat diet with oral gavage.

Osteoporosis decreases bone quality and strength. As a result, bones become brittle and fractures occur 

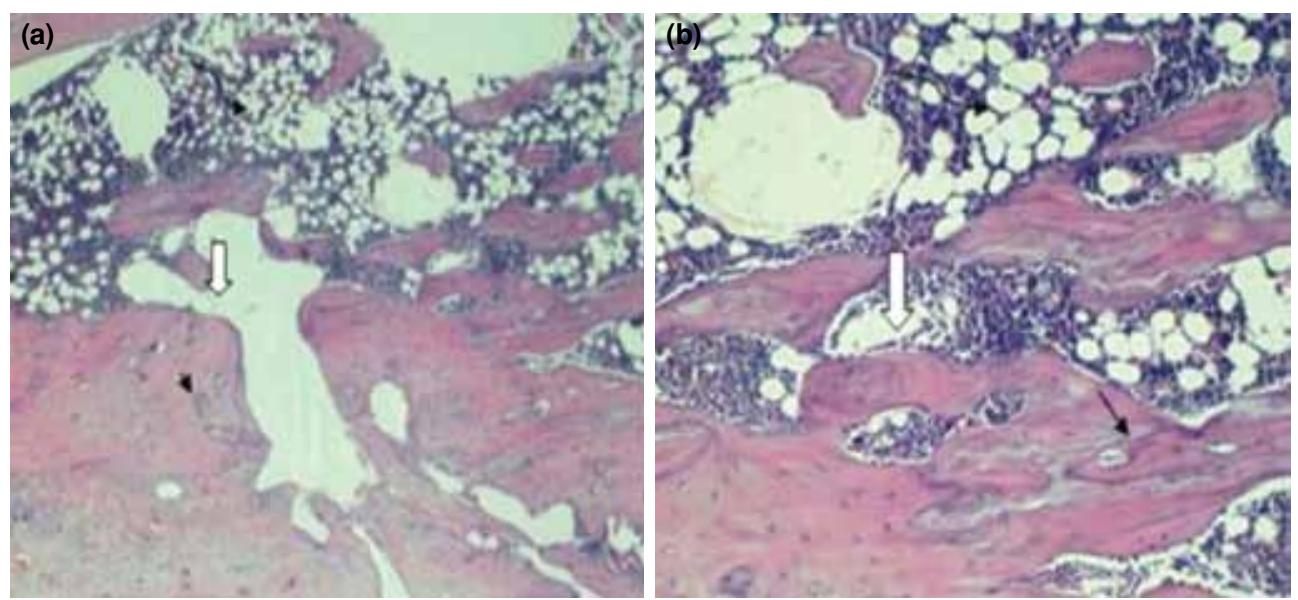

Figure 3. Straight black arrows show cement lines. White arrows show increased cortical thickness. Curved arrows show increased mature bone trabeculae in medullar cavity, (a) magnified x40 times and (b) magnified $\times 100$ times.

even with minor trauma. There are many efforts to increase the biomechanical and histological bone characteristics in state of osteoporosis both before and after fracture occurrence. ${ }^{[24]}$ Kiely et al. ${ }^{[25]}$ were the first to show new bone formation stimulation in an experimental study. They clearly demonstrated that zoledronic acid treatment increased new bone formation. In our study, rats in zoledronic acid treated groups had better bone histology and biomechanical characteristics. The significant increase in peak torque at failure means increased bone mineral content and enhanced bone microarchitecture or both. These effects cannot be explained solely with antiresorptive effects of zoledronic acid. There must be some other mechanisms besides the antiresorptive effect to explain the significant increase in bone strength and histological new bone formation. Russel ${ }^{[26]}$ argued that new bone formative effect of zoledronic acid may be due to stimulation of osteoblasts via mevalonate pathway.

Historically, many foods and mineral supplements were accepted as bone strengtheners in osteoporosis. In our study, addition of calcium and vitD treatment to zoledronic acid therapy did not contribute to fracture healing. There are conflicting results showing beneficial effects of dietary supplemental calcium and vitD on bone strength in osteoporotic rats. ${ }^{[27]}$

Histological examination of the species revealed that zoledronic acid treatment not only increases callus formation but also improves trabecular microarchitecture. Staining with hematoxylin and eosin led us to make clear distinction of woven and mature bone and also periosteal and medullary fibrosis. In this fracture model, endochondral ossification prevails the bone healing process. Later

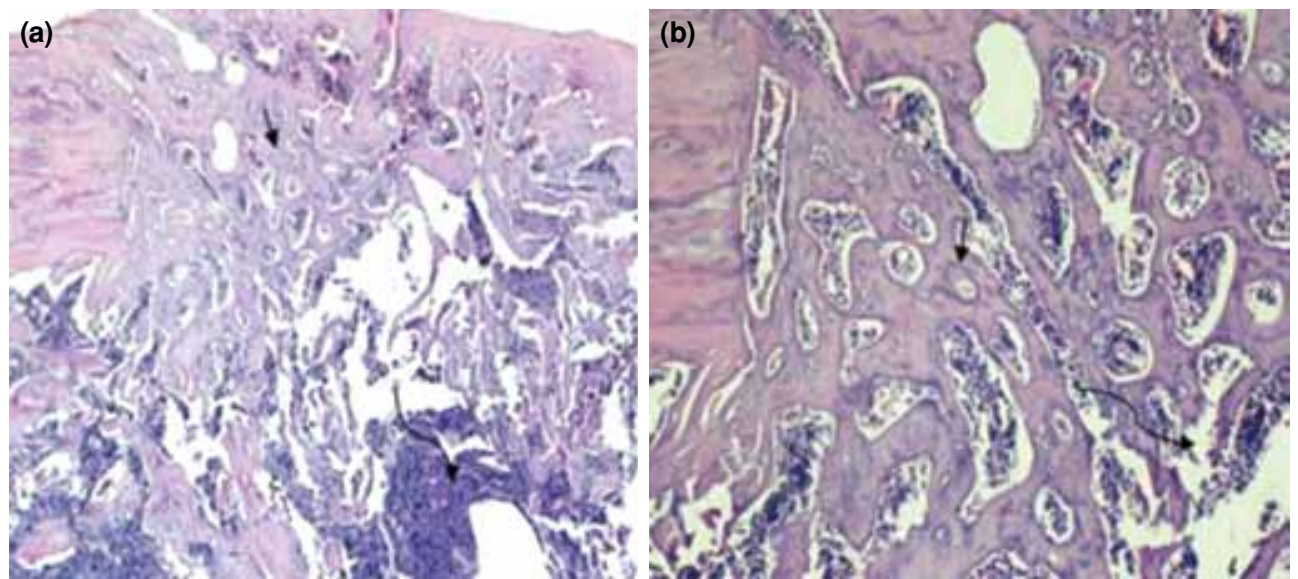

Figure 4. Straight black arrows show the cement lines, curved arrows show collapsed medullar cavity, (a) magnified $\times 40$ times and (b) magnified x100 times. 
on, this nonmineralized cartilage scaffold (woven bone) is replaced with new bone formed by osteoblasts. This is the stage where osteoclastic resorption starts indicating beginning of remodeling. There is an ongoing argument that antiresorptive agents might hinder bone healing. ${ }^{[28]}$ However, in our study, the specimens which received zoledronic acid treatment showed larger callus volume and increased woven and trabecular bone. These findings suggest that zoledronic acid treatment in an osteoporotic bone model not only stimulates primary bone production but also enhances retention of trabecular bone due to inhibition of remodeling.

There are some limitations of this study. First, the callus size of the fracture sites was not evaluated with micro-computed tomography analysis. This technique provides more detailed information on the callus volume. Second, serum zoledronate concentration was not detected because of technical difficulties.

In conclusion, fracture healing in an osteoporotic rat bone model was significantly increased via subcutaneous administration of zoledronic acid as shown by biomechanical and histological means. This effect was not influenced by oral calcium and vitD supplementation.

\section{Declaration of conflicting interests}

The authors declared no conflicts of interest with respect to the authorship and/or publication of this article.

\section{Funding}

The authors declare that this study was funded by Kırıkkale University Scientific Research Project.

\section{REFERENCES}

1. Consensus development conference: diagnosis, prophylaxis, and treatment of osteoporosis. Am J Med 1993;94:646-50.

2. Yamaguchi K, Masuhara K, Yamasaki S, Nakai T, Fuji T. Cyclic therapy with etidronate has a therapeutic effect against local osteoporosis after cementless total hip arthroplasty. Bone 2003;33:144-9.

3. Lugero GG, de Falco Caparbo V, Guzzo ML, König B Jr, Jorgetti V. Histomorphometric evaluation of titanium implants in osteoporotic rabbits. Implant Dent 2000;9:303-9.

4. Atik OS. What do we know about the ocular adverse effects associated with intravenous bisphosphonates? Eklem Hastalik Cerrahisi 2011;22:1.

5. Atik OS, Oztürk AM, Kunat C, Cetinkaya M, Kaptan Y. Do atypical femoral fractures in patients with prolonged alendronate treatment heal? Eklem Hastalik Cerrahisi 2014;25:52-5.

6. Ayanaoğlu T, Atik OŞ, Tokgöz N, Uçar M. Sacral and pubic insufficiency fractures due to bisphosphonate treatment. Eklem Hastalik Cerrahisi 2015;26:120-4.

7. Black DM, Delmas PD, Eastell R, Reid IR, Boonen S,
Cauley JA, et al. Once-yearly zoledronic acid for treatment of postmenopausal osteoporosis. N Engl J Med 2007;356:1809-22.

8. Khajuria DK, Razdan R, Mahapatra DR. Zoledronic acid in combination with alfacalcidol has additive effects on trabecular microarchitecture and mechanical properties in osteopenic ovariectomized rats. J Orthop Sci 2014;19:646-56.

9. Ammann P, Badoud I, Barraud S, Dayer R, Rizzoli R. Strontium ranelate treatment improves trabecular and cortical intrinsic bone tissue quality, a determinant of bone strength. J Bone Miner Res 2007;22:1419-25.

10. Bain SD, Jerome C, Shen V, Dupin-Roger I, Ammann P. Strontium ranelate improves bone strength in ovariectomized rat by positively influencing bone resistance determinants. Osteoporos Int 2009;20:1417-28.

11. Habermann B, Kafchitsas K, Olender G, Augat P, Kurth A. Strontium ranelate enhances callus strength more than PTH 1-34 in an osteoporotic rat model of fracture healing. Calcif Tissue Int 2010;86:82-9.

12. Khajuria DK, Disha C, Razdan R, Mahapatra DR. Comparative evaluation of zoledronic acid, alfacalcidol, and propranolol in pharmacological correction of experimental osteoporosis. Lat Am J Pharm 2013;32:968-76.

13. Komatsubara S, Mori S, Mashiba T, Nonaka K, Seki A, Akiyama T, et al. Human parathyroid hormone (1-34) accelerates the fracture healing process of woven to lamellar bone replacement and new cortical shell formation in rat femora. Bone 2005;36:678-87.

14. Manabe T, Mori S, Mashiba T, Cao Y, Kaji Y, Iwata K, et al. Eel calcitonin (elcatonin) suppressed callus remodeling but did not interfere with fracture healing in the femoral fracture model of cynomolgus monkeys. J Bone Miner Metab 2009;27:295-302.

15. Murphy CM, Schindeler A, Cantrill LC, Mikulec K, Peacock L, Little DG. PTH(1-34) Treatment Increases Bisphosphonate Turnover in Fracture Repair in Rats. J Bone Miner Res 2015;30:1022-9.

16. Bonnarens F, Einhorn TA. Production of a standard closed fracture in laboratory animal bone. J Orthop Res 1984;2:97-101.

17. Waynforth HB. Experimental and surgical technique in the rat. New York: Academic Press; 1980. p. 161-3.

18. Taguchi Y, Pereira BP, Kour AK, Pho RW, Lee YS. Autoclaved autograft bone combined with vascularized bone and bone marrow. Clin Orthop Relat Res 1995;320:220-30.

19. Uchida A, Nade S, McCartney E, Ching W. Bone ingrowth into three different porous ceramics implanted into the tibia of rats and rabbits. J Orthop Res 1985;3:65-77.

20. Ozturan KE, Demir B, Yucel I, Cakıcı H, Yilmaz F, Haberal A. Effect of strontium ranelate on fracture healing in the osteoporotic rats. J Orthop Res 2011;29:138-42.

21. Kalu DN, Liu CC, Salerno E, Hollis B, Echon R, Ray M. Skeletal response of ovariectomized rats to low and high doses of 17 beta-estradiol. Bone Miner 1991;14:175-87.

22. Das AS, Mukherjee M, Mitra C. Evidence for a prospective anti-osteoporosis effect of black tea (Camellia Sinensis) extract in a bilaterally ovariectomized rat model. Asia Pac J Clin Nutr 2004;13:210-6.

23. Khajuria DK, Razdan R, Mahapatra DR. Zoledronic acid in combination with alfacalcidol has additive effects on trabecular microarchitecture and mechanical properties in osteopenic ovariectomized rats. J Orthop Sci 2014;19:646-56. 
24. Greendale GA, Barrett-Connor E, Ingles S, Haile R. Late physical and functional effects of osteoporotic fracture in women: the Rancho Bernardo Study. J Am Geriatr Soc 1995;43:955-61.

25. Kiely P, Ward K, Bellemore C M, Briody J, Cowell CT, Little DG. Bisphosphonate rescue in distraction osteogenesis: a case series. J Pediatr Orthop 2007;27:467-71.
26. Russell RG. Bisphosphonates: from bench to bedside. Ann N Y Acad Sci 2006;1068:367-401.

27. Fu L, Tang T, Miao Y, Hao Y, Dai K. Effect of 1,25-dihydroxy vitamin D3 on fracture healing and bone remodeling in ovariectomized rat femora. Bone 2009;44:893-8.

28. Matos MA, Tannuri U, Guarniero R. The effect of zoledronate during bone healing. J Orthop Traumatol 2010;11:7-12. 